\title{
Pengaruh Penambahan Tepung Bulu Ayam dan Pati Kulit Pisang Terhadap Sifat Mekanik dan Biodegradabilitas Plastik Campuran Polipropilena Bekas
}

\author{
Pajri Marpin*,, Sri Mulyadi, Sri Handani \\ Jurusan Fisika Universitas Andalas \\ *pajrimarpin@rocketmail.com
}

\begin{abstract}
ABSTRAK
Telah dilakukan penelitian tentang pengaruh penambahan tepung bulu ayam dan pati kulit pisang terhadap sifat mekanik dan biodegradabilitas plastik campuran polipropilena bekas. Pada penelitian ini dibuat dua macam sampel yaitu pertama sampel dengan variasi tepung bulu ayam $0,2,4$ dan $6 \mathrm{~g}$ dengan penambahan pati kulit pisang $10 \mathrm{~g}$ dan sampel kedua dengan variasi pati 0,2, 4 dan $6 \mathrm{~g}$ dengan penambahan tepung bulu ayam $10 \mathrm{~g}$. Sampel-sampel tersebut kemudian diuji kuat lentur, kuat tarik dan degradabilitasnya. Pengujian degradabilitas dilakukan dengan cara penguburan selama 40 hari. Dari hasil penguburan dilihat pengurangan massanya. Hasil menunjukkan penambahan pati kulit pisang cenderung menurunkan kekuatan mekanis, namun mempercepat proses degradasi. Nilai maksimum kuat lentur terdapat pada sampel dengan variasi tepung bulu ayam $4 \mathrm{~g}$ dan $6 \mathrm{~g}$ senilai 19,60 N/mm². Nilai kuat tarik maksimum yaitu pada variasi $0 \mathrm{~g}$ pati kulit pisang sebesar $1,04 \mathrm{~N} / \mathrm{mm}^{2}$ dan nilai degradasi maksimum didapat pada sampel dengan pati kulit pisang $6 \mathrm{~g}$ yaitu $0,146 \%$ /hari.

Kata kunci : degradabilitas, kuat lentur, kuat tarik, pati kulit pisang, polipropilena, tepung bulu ayam
\end{abstract}

\section{ABSTRACT}

The research on the effect of adding quill powder and starch banana peel on mechanical properties and biodegradability polypropylene scrap plastic mixture has been conducted. In this study two kinds of samples are performed, the first samples with variations quill powder 0, 2, 4 and $6 \mathrm{~g}$ by adding $10 \mathrm{~g}$ of starch banana peel, while the second sample with variation of starch 0, 2, 4 and $6 \mathrm{~g}$ with the addition 10 $g$ of quill powder. Samples then were tested on bending strength, tensile strength and degradability. Degradability testing was done by burying the sample for 40 days. The reduction mass of samples can be analyzed by the effect of burial. The results show that the addition of starch banana peel tends to decrease the bending strength, but accerelate the degradation process. The maximum value of tensile strength was $19.60 \mathrm{~N} / \mathrm{mm}^{2}$ for the sample with $4 \mathrm{~g}$ and $6 \mathrm{~g}$ quill powder variations. The maximum value of tensile strength was $1.04 \mathrm{~N} / \mathrm{mm}^{2}$ for the sample with $0 \mathrm{~g}$ starch banana peel variation and maximum degradation value was obtained $0.146 \%$ day in the sample with $6 \mathrm{~g}$ starch banana peel variation.

Keyword : bending strength, degradability, polypropylene, quill powder, starch banana peel, tensile strength

\section{PENDAHULUAN}

Plastik merupakan salah satu bahan polimer kimia yang banyak digunakan dalam kehidupan manusia. Hal ini karena plastik memiliki keunggulan dibandingkan bahan polimer lain di antaranya ringan, kuat, transparan, tahan air serta harganya relatif lebih murah. Seiring dengan meningkatnya konsumsi plastik, jumlah sampah plastik juga meningkat. Plastik merupakan sampah yang berbahaya dan sulit dikelola. Penimbunan sampah plastik dalam tanah akan merusak tanah, karena sukar diuraikan oleh mikroorganisme.

Sampah plastik merupakan produk polimer sintetis yang tidak dapat terdegradasi secara alamiah oleh mikroba. Hal ini disebabkan karena struktur kimia plastik mempunyai bobot melekul tinggi dan pada umumnya memiliki rantai ikatan yang kuat sehingga plastik membutuhkan waktu yang lama terurai di alam. Dengan adanya persoalan mengenai limbah yang dihasilkan plastik, maka penelitian diarahkan pada pembuatan plastik yang dapat terurai di alam, salah satu penelitian terbaru adalah ditemukannya plastik biodegradabel. Plastik biodegradabel adalah plastik yang dapat digunakan layaknya plastik konvensional, namun akan hancur terurai oleh aktivitas mikroorganisme.

Salah satu jenis plastik biodegradabel adalah plastik berbasiskan pati. Yang dimanfaatkan pada pembuatan plastik biodegradabel yaitu berasal dari kulit pisang kepok karena pisang kepok kandungan patinya lebih tinggi dibandingkan dengan kulit buah yang lain, 
kulit semangka kandungan patinya 2,3\%, kulit durian kandungan patinya 5\%, sedangkan kulit pisang kepok kandungan patinya lebih tinggi yaitu 11,48\% (Direktorat Gizi Depkes RI 1981).

Pembuatan plastik dengan penambahan material pati dapat mempermudah proses degradasi oleh bakteri dengan cara memutus rantai polimer menjadi monomer-monomernya (Vilproux dan Averous 2006). Senyawa hasil degradasi polimer akan menghasilkan karbon dioksida dan air, serta menghasilkan senyawa organik lain yaitu asam organik dan aldehid yang tidak berbahaya bagi lingkungan (Ningsih, dkk 2012).

Penambahan pati kulit pisang pada plastik dapat mengurangi kekuatan mekanisnya, oleh karena itu dibutuhkan bahan lain untuk meningkatkan kekuatan mekanis tersebut. Salah satu bahan yang dapat meningkatkan kekuatan mekanis plastik yaitu bulu ayam, karena di dalamnya terdapat protein keratin yang memiliki kemampuan untuk membentuk plastik (Schrooyen, dkk 2001). Stabilitas keratin pada kondisi padat disebabkan adanya ikatan silang yang diproduksi dari pembentukan ikatan disulfida, ikatan hidrogen dan ikatan garam (Woodin 1954). Hal inilah yang menjadikan protein tangguh dan ringan sehingga dapat digunakan sebagai pengisi plastik yang berfungsi untuk meningkatkan kekuatan mekanis pada plastik biodegradabel.

\section{METODE}

Bahan yang digunakan pada penelitin ini adalah Plastik PP, tepung bulu ayam, dan pati kulit pisang yang kemudian dilebur menggunakan hot plate di dalam gelas kimia. Pada penelitian ini dibuat dua macam sampel yaitu pertama sampel dengan variasi tepung bulu ayam $0,2,4$ dan $6 \mathrm{~g}$ dengan penambahan pati kulit pisang $10 \mathrm{~g}$ dan sampel kedua dengan variasi pati kulit pisang 0, 2, 4 dan $6 \mathrm{~g}$ dengan penambahan tepung bulu ayam $10 \mathrm{~g}$. Campuran tersebut dicetak sesuai dimensi pengujian sampel. Pengujian sifat mekanis didasarkan pada standar American Society for Testing and Materials (ASTM). Uji Lentur menggunakan ASTM D790 dengan Persamaan 1

$$
f r=\frac{3 p l}{2 B H^{2}}
$$

dengan $p$ adalah beban patah maksimum, $l$ adalah jarak tumpuan, $B$ adalah lebar rata-rata benda uji, $H$ adalah tebal rata-rata benda uji. Kemudian uji tarik menggunakan ASTM D638 dengan Persamaan 2

$$
\sigma=\frac{F}{A}
$$

dengan $\sigma$ adalah kuat tarik, $F$ adalah gaya tarikan, dan $A$ adalah luas penampang. Untuk menghitung degradabilitas dihitung dengan menentukan persentase kehilangan massa. Persentase kehilangan massa dapat ditentukan dengan Persamaan 3

$$
\% m=\frac{m i-m f}{m i} \times 100 \%
$$

dengan $m i$ adalah massa sampel sebelum proses penguburan dan $m f$ adalah massa sampel setelah penguburan. Degradabilitas perhari dapat ditentukan dengan Persamaan 4

$$
D=\frac{\% m}{t}
$$

\section{HASIL DAN DISKUSI}

\subsection{Hasil Pengujian Kuat Lentur Plastik Campuran Polipropilena, Pati kulit Pisang, dan Tepung Bulu Ayam}

Pengujian kuat lentur dilakukan untuk mengetahui ketahanan suatu bahan terhadap pembebanan pada titik lentur. Hasil perhitungan kuat lentur plastik campuran polipropilena, pati kulit pisang, dan tepung bulu ayam dapat dilihat pada Tabel 1 . 
Tabel 1 Hasil Pengujian Kuat Lentur Plastik Campuran Polipropilena, Pati kulit Pisang, dan tepung bulu ayam.

\begin{tabular}{|c|c|c|c|c|}
\hline \multirow{2}{*}{ Variasi Sampel } & \multicolumn{3}{|c|}{ Kuat Lentur (N/mm²) } & \multirow{2}{*}{$\begin{array}{c}\text { Rata- Rata kuat Lentur } \\
\left(\mathbf{N} / \mathbf{m m}^{2}\right)\end{array}$} \\
\hline & Sampel 1 & Sampel 2 & Sampel 3 & \\
\hline $\begin{array}{l}60 \mathrm{~g} P P+10 \mathrm{~g} \\
\text { pati kulit } \\
\text { pisang }+0 \mathrm{~g} \\
\text { tepung bulu } \\
\text { ayam }\end{array}$ & 11,76 & 11,76 & 5,88 & $9,80 \pm 3,39$ \\
\hline $\begin{array}{l}60 \mathrm{~g} \mathrm{PP}+10 \mathrm{~g} \\
\text { pati kulit } \\
\text { pisang }+2 \mathrm{~g} \\
\text { tepung bulu } \\
\text { ayam }\end{array}$ & 11,76 & 11,76 & 11,76 & $11,76 \pm 0,00$ \\
\hline $\begin{array}{l}60 \mathrm{~g} \mathrm{PP}+10 \mathrm{~g} \\
\text { pati kulit } \\
\text { pisang }+4 \mathrm{~g} \\
\text { tepung bulu } \\
\text { ayam }\end{array}$ & 17,64 & 17,64 & 23,52 & $19,60 \pm 3,39$ \\
\hline $\begin{array}{l}60 \mathrm{~g} \mathrm{PP}+10 \mathrm{~g} \\
\text { pati kulit } \\
\text { pisang }+6 \mathrm{~g} \\
\text { tepung bulu } \\
\text { ayam }\end{array}$ & 17,64 & 23,52 & 17,64 & $19,60 \pm 3,39$ \\
\hline $\begin{array}{l}60 \mathrm{~g} P P+0 \mathrm{~g} \\
\text { pati kulit } \\
\text { pisang }+10 \mathrm{~g} \\
\text { tepung bulu } \\
\text { ayam }\end{array}$ & 17,64 & 17,64 & 17,64 & $17,64 \pm 0,00$ \\
\hline $\begin{array}{l}60 \mathrm{~g} P P+2 \mathrm{~g} \\
\text { pati kulit } \\
\text { pisang }+10 \mathrm{~g} \\
\text { tepung bulu } \\
\text { ayam }\end{array}$ & 11,76 & 17,64 & 23,52 & $17,64 \pm 0,00$ \\
\hline $\begin{array}{l}60 \mathrm{~g} P P+4 \mathrm{~g} \\
\text { pati kulit } \\
\text { pisang }+10 \mathrm{~g} \\
\text { tepung bulu } \\
\text { ayam }\end{array}$ & 11,76 & 17,64 & 17,64 & $15,68 \pm 3,39$ \\
\hline $\begin{array}{l}60 \mathrm{~g} \text { PP }+6 \mathrm{~g} \\
\text { pati kulit } \\
\text { pisang }+10 \mathrm{~g} \\
\text { tepung bulu } \\
\text { ayam }\end{array}$ & 11,76 & 17,64 & 17,64 & $15,68 \pm 0,00$ \\
\hline
\end{tabular}

Grafik hubungan kuat lentur plastik campuran polipropilena, pati kulit pisang, dan tepung bulu ayam ditampilkan pada Gambar 1. Pada Gambar 1(a) dapat dilihat bahwa penambahan komposisi tepung bulu ayam cenderung menyebabkan peningkatan kuat lentur bahan. Hal ini karena tepung bulu ayam memiliki sifat mekanik yang cukup baik terutama rasio antara kekuatan tarik dengan berat jenisnya. 

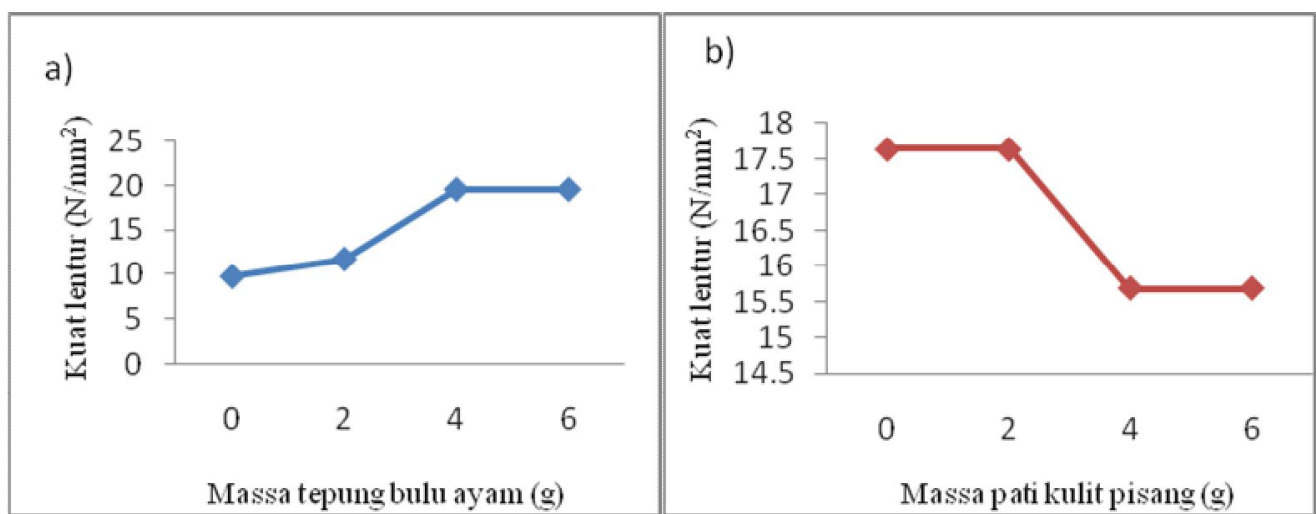

Gambar 1 Grafik hubungan kuat lentur plastik polipropilena terhadap (a) variasi tepung bulu ayam (b) variasipati kulit pisang.

Sebaliknya pada Gambar 1 (b) dengan penambahan pati kulit pisang nilai kuat lentur cenderung menurun. Hal ini disebabkan pati kulit pisang yang berfungsi sebagai bahan pengisi berupa pati menyebabkan penurunan sifat mekanik dari plastik. Penambahan jumlah pati pada komposit menyebabkan rendahnya interaksi permukaan (interfacial) polimer (Kim dan Lee, 2002). Semakin meningkat kandungan pati semakin meningkat fase tidak homogen atau tidak kompatibel komposit.

\subsection{Hasil Pengujian Kuat Tarik Plastik Campuran Polipropilena, Pati kulit Pisang, dan Tepung Bulu Ayam}

Pengujian kuat tarik bertujuan untuk menentukan batas gaya tarik yang dapat diberikan pada sampel per satuan luas. Dari Tabel 2 dapat dilihat hasil pengujian kuat tarik plastik campuran polipropilena, pati kulit pisang dan tepung bulu ayam.

Tabel 2 Hasil pengujian kuat tarik plastik campuran polipropilena, pati kulit pisang,dan tepung bulu ayam.

\begin{tabular}{|c|c|c|c|c|}
\hline \multirow{2}{*}{ Variasi sampel } & \multicolumn{3}{|c|}{ Kuat Tarik $\left(\mathbf{N} / \mathbf{m m}^{2}\right)$} & \multirow{2}{*}{$\begin{array}{c}\text { Rata- Rata Kuat Tarik } \\
\qquad\left(\mathrm{N} / \mathbf{m m}^{2}\right)\end{array}$} \\
\hline & Sampel 1 & Sampel 2 & Sampel 3 & \\
\hline $\begin{array}{l}60 \mathrm{~g} P P+10 \mathrm{~g} \\
\text { pati kulit } \\
\text { pisang }+0 \mathrm{~g} \\
\text { tepung bulu } \\
\text { ayam }\end{array}$ & 0,19 & 0,19 & 0,19 & $0,19 \pm 0,00$ \\
\hline $\begin{array}{l}60 \mathrm{~g} P P+10 \mathrm{~g} \\
\text { pati kulit } \\
\text { pisang }+2 \mathrm{~g} \\
\text { tepung bulu } \\
\text { ayam }\end{array}$ & 0,39 & 0,39 & 0,39 & $0,39 \pm 0,00$ \\
\hline $\begin{array}{l}60 \mathrm{~g} P P+10 \mathrm{~g} \\
\text { pati kulit } \\
\text { pisang }+4 \mathrm{~g} \\
\text { tepung bulu } \\
\text { ayam }\end{array}$ & 0,78 & 0,19 & 0,19 & $0,39 \pm 0,39$ \\
\hline $\begin{array}{l}60 \mathrm{~g} P P+10 \mathrm{~g} \\
\text { pati kulit } \\
\text { pisang }+6 \mathrm{~g} \\
\text { tepung bulu } \\
\text { ayam }\end{array}$ & 0,78 & 0,19 & 1,76 & $0,39 \pm 0,79$ \\
\hline
\end{tabular}




\begin{tabular}{|c|c|c|c|c|}
\hline $\begin{array}{l}60 \mathrm{~g} \mathrm{PP}+0 \mathrm{~g} \\
\text { pati kulit } \\
\text { pisang }+10 \mathrm{~g} \\
\text { tepung bulu } \\
\text { ayam }\end{array}$ & 1,17 & 0,58 & 1,37 & $1,04 \pm 0,41$ \\
\hline $\begin{array}{l}60 \mathrm{~g} \mathrm{PP}+2 \mathrm{~g} \\
\text { pati kulit } \\
\text { pisang }+10 \mathrm{~g} \\
\text { tepung bulu } \\
\text { ayam }\end{array}$ & 0,98 & 0,78 & 0,78 & $0,84 \pm 0,11$ \\
\hline $\begin{array}{l}60 \mathrm{~g} \mathrm{PP}+4 \mathrm{~g} \\
\text { pati kulit } \\
\text { pisang }+10 \mathrm{~g} \\
\text { tepung bulu } \\
\text { ayam }\end{array}$ & 0,78 & 0,98 & 0,78 & $0,78 \pm 0,11$ \\
\hline $\begin{array}{l}60 \mathrm{~g} \mathrm{PP}+6 \mathrm{~g} \\
\text { pati kulit } \\
\text { pisang }+10 \mathrm{~g} \\
\text { tepung bulu } \\
\text { ayam }\end{array}$ & 0,58 & 0,78 & 0,58 & $0,65 \pm 0,11$ \\
\hline
\end{tabular}

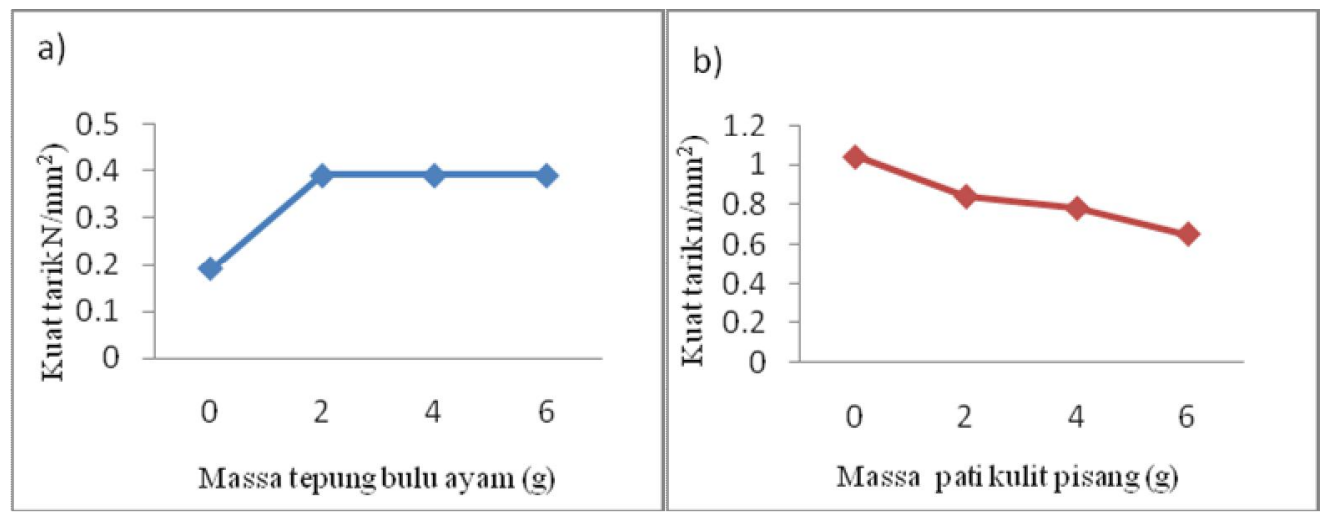

Gambar 2 Grafik hubungan kuat tarik plastik propilena terhadap (a) variasi tepung bulu ayam (b) variasi pati kulit pisang.

Grafik hubungan kuat tarik plastik campuran polipropilena, pati kulit pisang, dan tepung bulu ayam yang dapat dilihat pada Gambar 2. Dari Gambar 2(a) dapat dilihat dengan penambahan komposisi tepung bulu ayam plastik dapat menaikkan nilai kuat tarik dari plastik, karena pada bulu ayam terdapat protein keratin yang tangguh dan ringan sehingga dapat digunakan sebagai pengisi plastik yang berfungsi untuk meningkatkan kekuatan mekanis pada plastik tersebut. Kemudian pada Gambar 2 (b) dapat dilihat penambahan pati kulit pisang dapat menurunkan nilai kuat tarik plastik, hal ini disebabkan karena pencampuran plastik dengan pati menyebabkan sifat plastisnya menjadi lemah, seperti kekuatan tarik, kekuatan mulur, perpanjangan putus, stabilitas kelembaban yang rendah dan melepaskan molekul pemlastis dalam jumlah kecil dari matrik pati (Zhang, 2007) dan pati kulit pisang bersifat non plastis sehingga membuat sifat plastis menjadi berkurang yang dapat menyebabkan plastik rapuh dan mudah patah.

\subsection{Hasil Pengujian Degradabilitas Plastik campuran Polipropilena, Pati Kulit Pisang, danTepung Bulu Ayam}

Pengujian degradabilitas bertujuan untuk menentukan laju perubahan massa sampel setelah penguburan. Proses degradasi dapat diketahui dengan cara melihat perubahan massa 
sampel plastik sebelum dan sesudah penguburan di dalam tanah, dalam rentang waktu tertentu. Pada Tabel 3 disajikan \% degradasi massa sampel setelah penguburan selama 40 hari.

Tabel 3 pengujian degradabilitas plastik campuran polipropilena, pati kulit pisang, dan tepung bulu ayam massa setelah penguburan 40 hari.

\begin{tabular}{|c|c|c|c|c|}
\hline \multirow[b]{2}{*}{ Variasi sampel } & \multicolumn{2}{|c|}{ Massa sampel } & \multirow[b]{2}{*}{ Persen massa $(\%)$} & \multirow[b]{2}{*}{ Degradasi $(\% /$ hari } \\
\hline & $\begin{array}{c}\text { Massa awal } \\
\text { (g) }\end{array}$ & $\begin{array}{c}\text { Massa akhir } \\
\text { (g) }\end{array}$ & & \\
\hline $\begin{array}{l}60 \mathrm{~g} \mathrm{PP}+10 \mathrm{~g} \\
\text { pati kulit pisang } \\
+0 \mathrm{~g} \text { tepung } \\
\text { bulu ayam }\end{array}$ & 2,224 & 2,138 & 3,886 & 0,096 \\
\hline $\begin{array}{l}60 \mathrm{~g} \mathrm{PP}+10 \mathrm{~g} \\
\text { pati kulit pisang } \\
+2 \mathrm{~g} \text { tepung } \\
\text { bulu ayam }\end{array}$ & 2,195 & 2,095 & 4,555 & 0,114 \\
\hline $\begin{array}{l}60 \mathrm{~g} \mathrm{PP}+10 \mathrm{~g} \\
\text { pati kulit pisang } \\
+4 \mathrm{~g} \text { tepung } \\
\text { bulu ayam }\end{array}$ & 2,246 & 2,126 & 5,342 & 0,133 \\
\hline $\begin{array}{l}60 \mathrm{~g} P P+10 \mathrm{~g} \\
\text { pati kulit } \\
\text { pisang }+6 \mathrm{~g} \\
\text { tepung bulu } \\
\text { ayam }\end{array}$ & 2,250 & 2,129 & 5,377 & 0,134 \\
\hline $\begin{array}{l}60 \mathrm{~g} \mathrm{PP}+0 \mathrm{~g} \\
\text { pati kulit pisang } \\
+10 \mathrm{~g} \text { tepung } \\
\text { bulu ayam }\end{array}$ & 2,135 & 2,133 & 0,093 & 0,002 \\
\hline $\begin{array}{l}60 \mathrm{~g} \mathrm{PP}+2 \mathrm{~g} \\
\text { pati kulit pisang } \\
+10 \mathrm{~g} \text { tepung } \\
\text { bulu ayam }\end{array}$ & 2,139 & 2,111 & 1,30 & 0,032 \\
\hline $\begin{array}{l}60 \mathrm{~g} \mathrm{PP}+4 \mathrm{~g} \\
\text { pati kulit pisang } \\
+10 \mathrm{~g} \text { tepung } \\
\text { bulu ayam }\end{array}$ & 2,168 & 2,121 & 2,167 & 0,054 \\
\hline $\begin{array}{l}60 \mathrm{~g} \mathrm{PP}+6 \mathrm{~g} \\
\text { pati kulit pisang } \\
+10 \mathrm{~g} \text { tepung } \\
\text { bulu ayam }\end{array}$ & 2,208 & 2,079 & 5,842 & 0,146 \\
\hline
\end{tabular}

Besar perubahan degradabilitas plastik dapat dilihat pada Gambar 3. Pada Gambar 3 (a) pada plastik dengan penambahan tepung bulu ayam semakin besar penambahan tepung bulu ayam pada plastik maka semakin besar tingkat degradasinya begitu pula dengan Gambar 3 (b) pada variasi pati kulit pisang semakin besar penambahan pati kulit pisang pada plastik maka degradasinya semakin cepat . kemudian pada gambar 3 (b) plastik dengan penambahan pati kulit pisang tingkat degradasinya lebuh cepat dibandingkan dengan gambar 3 (a) pada variasi tepung bulu ayam. Ini disebabkan karena mikroba lebih menyukai pati kulit pisang dibandingkan tepung bulu ayam. 

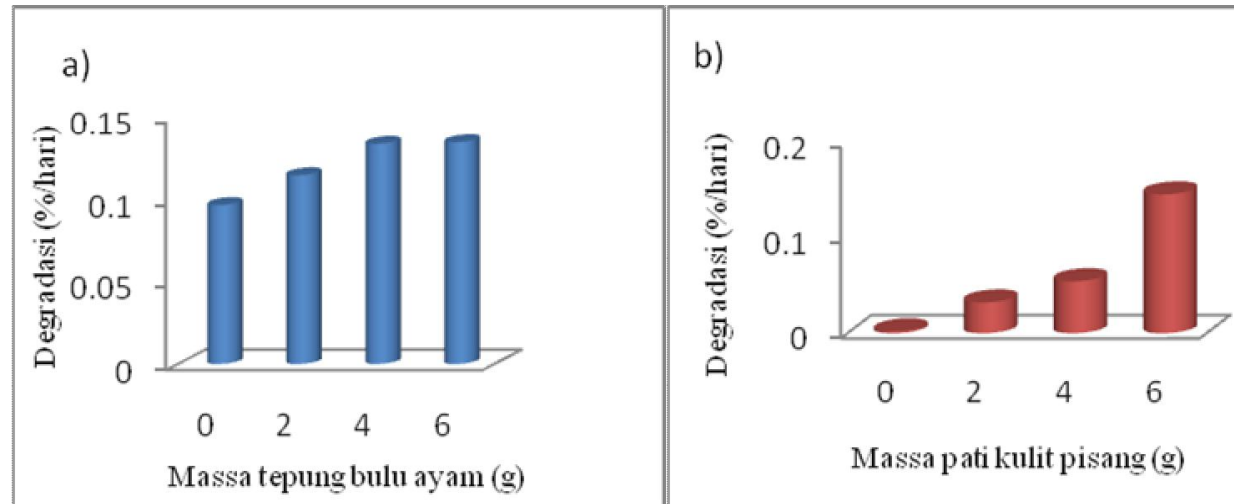

Gambar 3 Grafik hubungan degradasi plastik polipropilena terhadap (a) variasi tepung bulu ayam

(b) variasi pati kulit pisang.

Bentuk morfologi sampel dapat dilihat menggunakan Scanning Electron Microscope (SEM), Hasil SEM dapat dilihat pada Gambar 4. Dari Gambar 4 (a) terlihat bahwa terjadi kerusakan sampel setelah dilakukan penguburan. Hal ini ditandai dengan bentuk sampel sebelum penguburan terlihat struktur permukaan sampel lebih halus dibanding dengan Gambar (b) pada sampel setelah penguburan terlihat bentuk permukaan sampel menjadi kasar. Hal ini menunjukkan penambahan pati dan pemlastis mengakibatkan komposit yang terbentuk disukai mikroba sehingga banyak terbentuk pori pada permukaan sampel yang dikubur dalam tanah. Banyaknya pori yang terbentuk bergantung pada banyak atau tidaknya mikroba yang menyerang komposit. Semakin banyak pati yang disukai mikroba maka semakin cepat degradasi yang terjadi.

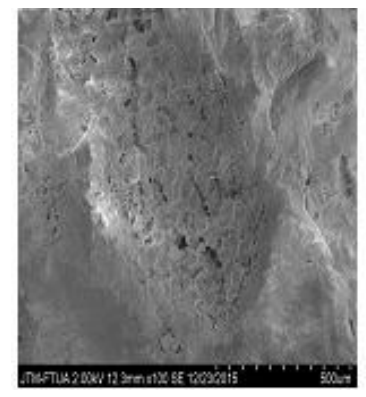

(a)

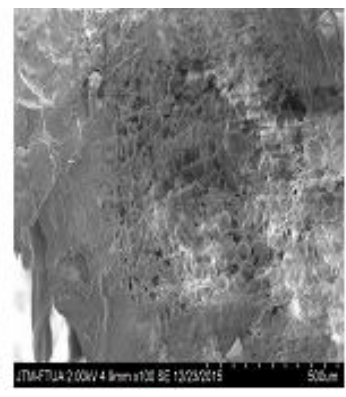

(b)

Gambar 4 (a) Sampel sebelum penguburan (b) sampel sesudah penguburan

\section{KESIMPULAN}

Dari penelitian yang telah dilakukan mengenai plastik Polipropilena campuran tepung bulu ayam dan pati kulit pisang, maka dapat disimpulkan. Bahwa nilai maksimum kuat lentur terdapat pada komposit dengan variasi tepung bulu ayam $4 \mathrm{~g}$ dan $6 \mathrm{~g}$ senilai 19,60 N/mm2. Nilai kuat tarik maksimum terdapat pada variasi pati kulit pisang $0 \mathrm{~g}$ sebesar 1,04 N/mm2 dan nilai degradasi tertinggi didapat pada sampel dengan variasi pati kulit pisang $6 \mathrm{~g}$ yaitu $0,146 \%$ /hari. Penambahan pati dapat mengakibatkan kekuatan mekanik komposit yang terbentuk menjadi menurun, namun dengan penambahan pati akan membuat komposit lebih disukai mikroba sehingga plastik lebih cepat terurai, hal ini terlihat pada hasil Scanning Electron Microscope (SEM). Pada permukaan komposit yang telah dikubur selama 40 hari pada media tanah lebih banyak terdapat pori dengan persen massa yang didapat yaitu $5,842 \%$ dan nilai degradabilitas yaitu $0,146 \mathrm{~g} / \mathrm{hari}$.

\section{DAFTAR PUSTAKA}

Kim, M., dan Lee, S., CarbohydrPolym 50, hal.331-337 (2002).

Ningsih, E.S., Mulyadi, S., dan Yetri, Y., Jurnal Fisika 1, hal.20-30 (2012).

Schrooyen P.M.M..Dijkstra. P. P.J..Oberthur.R..Bantjes. A..\&Feijen. J, Journal of Agricultural and Food Chemistry 49.Hal.221-230 (2001). 
Vilproux, O., and Averous, L., Journal of Macro Molekuler Science 3, hal.521 (2006).

Woodin,A,M.,1954, Molecular Size Shape and Aggregration of Soluble Feather Keratin Biochemical Journal 57, hal.99-109 (1954).

Zhang, dkk., Polymer 48, hal. 7193-7200 (2007). 